\title{
Marpa's commands in the Milarepa Life Story
}

\author{
John Pickens \\ University of California, Berkeley \\ johnpickens@berkeley.edu
}

\begin{abstract}
In the Milarepa Life Story the Buddhist teacher Marpa issues many commands to his student, Milarepa, his wife, Dakmema, and his co-religionist, Lama Ngokpa. In these commands the co-occurrence of the imperative stem (skul tshig) and a given pronoun or vocative (khyod, bu, rang re, etc.) indicates a varying level of distance between himself and the addressee. Marpa's speech is also nuanced by the use of pronouns, vocatives, and nicknames across a variety of registers. Marpa's interlocutors, however, invariably use honorific titles and the deferential verb zhu ba to make their requests. The contrast highlights Marpa's authority, as his speech alone determines how close he is with an interlocutor at a given time.
\end{abstract}

Keywords: Marpa, Milarepa, Commands, Vocative, Prounouns, Imperative, Classical Tibetan

\section{Introduction}

The Milarepa Life Story was written by Tsangnyön Heruka (Gtsang smyon he ru $k a, 1452-1507)^{1}$ in $1488 .^{2}$ The centrepiece of the biography is the relationship between Milarepa and his volatile Buddhist teacher Marpa. Marpa does not teach Milarepa when they first meet. Instead he forces him to complete many arduous tasks, most notably the construction of stone towers that must be built by hand and then torn down again. Marpa is particularly demanding of Milarepa in this part of the narrative, repeatedly commanding him to work on the towers. In Section I of this paper I examine Marpa's use of harsh directives

1 In this paper I am using the edition of the Milarepa Life Story input by Tibet in Digital Communication (http:/larkpie.net/tibetancorpus/). It follows a block print edition (117 folios) kept in The Library of Otani University (Zogai no. 11854) and corresponds closely to version "C" in the critical edition by Jan Willem de Jong, Mi la ras pa' $i$ rnam thar: texte tibétain de la vie de Milarépa (The Hague: Mouton, 1959). In the translations below I only make note of de Jong's critical edition when there is a significant or helpful variant. Andrew Quintman provides a comprehensive summary of the Milarepa Life Story corpus in his book The Yogin and the Madman: Reading the Biographical Corpus of Tibet's Great Saint Milarepa (New York: Columbia University Press, 2014), 11-7. On the life of Tsangnyön Heruka see Stefan Larsson, Crazy for Wisdom: The Making of a Mad Yogin in Fifteenth-Century Tibet (Leiden and Boston: Brill, 2005).

2 The colophon indicates the manuscript was completed "on the eighth day of the middle autumnal month of the Earth Monkey Year ( phur bu'i lo ston zla 'bring po' $i$ yar tshes brgyad la "). 1488 is the forty-second year in the eighth Tibetan cycle of 60 years (rabjung). 
that include the pronoun khyod and end with a verb in the imperative stem (skul tshig). Eventually Milarepa completes the assigned tasks and receives the desired Buddhist teachings. He practises meditation in a secluded cave and departs from Marpa as his esteemed student. In Section II I examine Marpa's commands that encourage Milarepa. Throughout the story Marpa also issues commands to his wife Dakmema (Bdag med ma) and co-religionist Lama Ngokpa (Bla ma rngog pa). Section III explores the speech of these interlocutors, who never use pronouns or the imperative stem. ${ }^{3}$ Milarepa, Dakmema, and Lama Ngokpa instead make formal requests using honorific titles, such as "Great Father Lama (yab bla ma chen po)", and the verb zhu ba ("I humbly request").

In the Milarepa Life Story the temper of Marpa's commands is usually communicated through the use of certain pronouns or vocatives. Marpa also addresses people with their proper names (e.g. Rngog ston chos rdor for Lama Ngokpa) and nicknames (e.g. Mthu chen "Great Magician" for Milarepa). ${ }^{4}$ Table 1 provides a list of the various pronouns and generic vocatives used by Marpa. ${ }^{5}$

Milarepa's rise in status is shown through terms of address that indicate his closer proximity to Marpa (e.g. from the dismissive "Hey you!" to the affectionate "Oh son"). Unlike other characters in Tsangnyön Heruka's work, Marpa uses pronouns, vocatives, and nicknames across a variety of registers. For example, the pronoun khyod (which is usually used to address Milarepa in a derogatory manner) is eventually used by Marpa to express close familiarity. The repertoire of terms used to address Milarepa (and others) accentuates Marpa's authority vis-à-vis his student, wife, and co-religionist.

\section{Derogatory commands}

In the Milarepa Life Story Marpa commonly issues commands that begin with the second person singular pronoun khyod. In Tibetan khyod is typically used to indicate lower social status, ${ }^{6}$ in contrast to the honorific khyed. ${ }^{7}$ Marpa

3 Marpa is addressed with the pluralis majestatis "khyed" on just a few occasions, and usually in conjunction with an honorific title. For example, Dakmema addresses Marpa "You, Great Teacher!" (khyed bla ma chenpo, 23b line 3).

4 Marpa (unlike his interlocutors) refers to himself as "Marpa". Milarepa is upbraided by Marpa before he even knows who he is talking to: "Is it true that you don't recognize me? I myself am Marpa. Prostrate!" (ngo mi shes pa bden yong / mar pa nga rang yin phyag tshol cig, 24b line 5).

5 Marpa uses the pronouns khyed gnyis ("you two") and 'o cag ("we two"), but without the imperative stem. He also addresses Milarepa with khyed in two variant readings. De Jong, Mi la ras pa'i rnam thar, 103, line 19, n. 25 and 105, line 24, n. 10. These variants reflect some textual instability in Marpa's use of pronouns. For a more thorough discussion of these variants see n. 23 .

6 Nathan W. Hill has found that khyod is neutral in Old Tibetan. It is used, for example, by a mother to her child, a wife to her husband, co-conspirators, and an emperor to his vassal; see "Personal pronouns in Old Tibetan", Journal Asiatique 298/2, 2010, 559. In the Milarepa Life Story, however, khyod is not neutral.

7 In Old Tibetan khyed is a second person plural pronoun. Only later did it emerge as the pluralis majestatis, an "honorific equivalent of khyod" (Nathan W. Hill, "The emergence 
Table 1. Pronouns and generic vocatives used by Marpa

\begin{tabular}{|c|c|}
\hline Pronouns and vocatives used by Marpa & Person(s) addressed \\
\hline You (khyod and khyod rang) & $\begin{array}{l}\text { Milarepa, Dakmema, and Lama } \\
\text { Ngokpa }\end{array}$ \\
\hline $\begin{array}{l}\text { Oh son }(b u) \text {, dear son (bu kho de), and you son } \\
(\text { bu khyod) }\end{array}$ & Milarepa \\
\hline Honorific you (khyed and khyed rang) & Lama Ngokpa, Milarepa \\
\hline $\begin{array}{l}\text { Us two (rang re and nga gnyis), father and son } \\
\text { (pha bu) }\end{array}$ & Milarepa \\
\hline
\end{tabular}

uses khyed very rarely, however, so this distinction cannot be exclusively relied on to distinguish the social position of his interlocutors. ${ }^{8}$ Instead, we must examine the range of pronouns, vocatives, nicknames, and verbal forms used by Marpa to indicate the status of the people he is speaking to. I begin this endeavour by looking at examples where he uses khyod (or the equivalent khyod rang) ${ }^{9}$ and the imperative stem in a derogatory manner.

of the pluralis majestatis and the relative chronology of Old Tibetan texts", in Franz-Karl Ehrhard and Petra Maurer (eds), Nepalica-Tibetica: Festgabe for Christoph Cüppers, Andiast: International Institute for Tibetan and Buddhist Studies, 2013, 250. Even though the pronoun khyed is clearly used as an honorific second person singular in the Milarepa Life Story it is not completely distinct from its origins as a second person plural. For example, Marpa addresses Milarepa and Dakmema as khyed gnyis (30b, line 3). For more examples see Nathan W. Hill, "Personalpronomina in der Lebensbeschreibung des Mi la ras pa, Kapitel Ill", Zentralasiatische Studien 36, 2007, 277-87.

8 Marpa only addresses Lama Ngokpa with khyed in a written letter (36a line 6). In two variant readings Marpa addresses Milarepa with khyed (see n. 23).

9 These two pronouns are used interchangeably throughout this section of the Milarepa Life Story. It is tempting to assert that khyod rang is slightly more polite than khyod, if only because it is a longer form. This thesis is supported by an instance when Marpa uses khyod rang to praise Milarepa: "You are one with very great diligence!" (khyod rang snying rus che rab cig 'dug, 26a line 5). Based on all the times Marpa uses khyod and khyod rang, however, any such conclusion is untenable. First, this is because the terms are often used in succeeding sentences. For example, when Marpa scolds his wife for giving away a piece of turquoise he states: "You did not think carefully! If I am fully your master, then the turquoise is surely under my control!" (khyod bsam mno ma cung / khyod rang ril po nga dbang na / gyu nga yi dbang yin mod, $31 \mathrm{~b}$ lines 5-6). Later, Marpa reprimands Milarepa for not bringing his own offering: "You may not use my wealth as your initiation offering! If you have your own then bring it! Otherwise, don't stay in the line of those receiving initiation!" (nga'i nor gyis khyod gyi dbang yon mi yong / khyod rang la yod na khyer shog de min nga'i dbang gral du ma sdod, 31b line 6). As in this example, khyod usually precedes khyod rang when they are used in successive sentences. In some commands this reads literally as "You, yourself", but has a sense like the English phrase "You and only you!" Still, one form does not appear to be more civil than the other. In another passage Marpa decodes all of Milarepa's actions since their first meeting, saying what each portends for his future. Here khyod and khyod rang are used interchangeably, in no discernible order (41b lines 1-4). 
At the beginning of chapter two Milarepa enters Marpa's house for the first time. He is immediately scolded after dropping his weighty offering of barley on the floor.

(1) khyod nged rnam kyang gtibs ${ }^{10}$ 'og tu lag mthus gsod snyam pa yin nam / nan tar ma 'tsham pas nas do ${ }^{11}$ phyir thon //

$\begin{array}{lllll}\begin{array}{l}\text { khyod } \\ \text { You-[ABS] }\end{array} & \begin{array}{l}\text { nged rnam } \\ \text { us-PL-[ABS] }\end{array} & \begin{array}{l}\text { kyang } \\ \text { also }\end{array} & \begin{array}{l}\text { gtibs } \\ \text { collapsed [house] }\end{array} & \begin{array}{c}\text { 'og tu } \\ \text { under-TRM }\end{array} \\ \begin{array}{llll}\text { lag mthus } & \text { gsod } & \text { snyam pa } & \text { yin nam / } \\ \text { hand-power-ERG } & \text { kill } & \text { think } & \text { is - QSN }\end{array}\end{array}$

$\begin{array}{llll}\text { nan tar } & \text { ma 'tsham pas } & \text { nas do phyir } & \text { thon // } \\ \text { Certainly } & \text { NEG-capable-because } & \text { barley outside-TRM } & \text { throw-IMP } 12\end{array}$

"Do you also imagine killing us by collapsing the house with your bare hands? Since you are certainly incapable, throw your barley outside!" (25a lines 6-25b line 1)

Later, Milarepa is told to cast a series of magical spells against Marpa's enemies. It is the first of a demanding series of preliminary tasks that he must undertake before receiving Buddhist teachings.

(2) khyod la mthu chen po yod zer ba / khyod rang la kha ba 'di rnams la mthu thong //

khyod la mthu chen po yod zer ba/

You-ALL great magical powers-[ABS] exist say

$\begin{array}{lll}\text { khyod rang } & \text { la kha ba } & \text { 'di rnams la mthu thong // } \\ \text { you-[ABS] } & \text { highlanders } & \text { this-PL-ALL cast magic-IMP }\end{array}$

"It's said that you have great magical powers. Cast black spells on these highlanders!" (25b line 6)

10 de Jong (Mi la ras pa'i rnam thar, 57 n. 14) gives a variant reading tibs. I am unsure of the etymology of gtibs or tibs, although in this context they may be related to the term rtib pa (to break or pull down). In a passage describing the result of a major earthquake, David Jackson also translates gtibs "og tu as "beneath collapsed houses": "All districts echoed with the fierce wailing of grief for the many people who had died beneath collapsed houses (mi mang po gtibs 'og tu shi bar gyur ba'i mya ngan gyi cho nge drag po "bying pas yul "khor thams cad du khyab cing)". "The Great Western-Himalayan Earthquake of 1505: a rupture of the Central Himalayan Gap?", in Henk Blezer and A. Zadoks (eds), Tibet, Past and Present (International Association for Tibetan Studies, PIATS 2000. Boston: Brill, 2000), 147. The phrase gtibs 'og $t u$ is also used earlier in the Life Story when Milarepa makes a house collapse, killing 35 of his relatives: khyim gtibs pa'i gtibs 'og tu a khu'i bu rnams dang gna' ma sogs mi mda' sum cu so lnga shi bas (16b lines 4-5). In example (1) above Marpa says "also (kyang)" in reference to this previous act.

11 All of de Jong's readings include the term $d o$ here. It is unclear what this term adds to the sentence and so I leave it untranslated.

12 The notation used for all examples is outlined in the abbreviations list at the end of the paper. 
During the construction of a stone building, Milarepa is told to stop working on a wall he is building and instead to start a new construction project.

(3) mthu chen khyod rang da re zhig mkhar gyi rtsig 'phro zhog la / zhol gyi rnam pa'i khyams ka ba bcug nyis yod pa btsan khang dang bcas pa cig rtsigs //

mthu chen khyod rang da re zhig mkhar gyi rtsig 'phro Great Magician-VOC You-[ABS] now fortress-GEN wall remainder zhog la / zhol gyi rnam pa'i khyams ka ba bcu nyis yod pa let be-and basis-GEN in the form-GEN twelve-pillared courtyard exist

$\begin{array}{llll}\text { btsan khang } & \text { dang bcas pa } & \text { cig } & \text { rtsigs // } \\ \text { stronghold } & \text { together with } & \text { a-[ABS] } & \text { build-IMP }\end{array}$

"Great Magician! For now forget about the remainder of the wall of the fortress! Build a stronghold together with a twelve-pillared courtyard at its base!" (29a lines 2-3)

As these examples show, Milarepa is forced to perform a series of seemingly arbitrary tasks. He is completely subservient to Marpa. Marpa also uses khyod with the imperative in order to reprimand Lama Ngokpa.

(4) rngog ston chos rdor zer ba'i ma bcol ba byed mkhan khyod rang nga'i na ro'i sku rgyan dang thugs dam rnams da lta rang long zhog cig //

$\begin{array}{llll}\text { rngog ston chos rdor } & \text { zer ba'i } & \text { ma bcol ba } & \text { byed mkhan } \\ \text { Rngog ston Chos rdor } & \text { called-GEN } & \text { NEG-permission } & \text { one who acted } \\ \text { khyod rang nga'i } & \text { na ro'i } & \text { sku rgyan } & \text { dang } \\ \text { You-VOC my-GEN Naro-GEN } & \text { body ornaments } & \text { and } \\ \text { thugs dam rnams } & \text { da lta rang } & \text { long zhog cig // } & \\ \text { ritual items-PL-[ABS] } & \text { immediately bring-IMP } & \end{array}$

"You, the one who has acted without permission, called Ngokton Chödor! Bring my ornaments of Naropa and ritual items immediately!" (39a line 2)

The use of Lama Ngokpa's full name in this context strengthens the force of the rebuke, much like a father using the full name of his son when he wants both to get his attention and tell him what to do.

In the Milarepa Life Story Marpa primarily uses the pronoun khyod (and khyod rang) with the imperative stem to enforce his authority. In this context, the grammatical use of the pronoun khyod combined with the imperative reflects the greatest distance between Marpa, who is all-powerful, and Milarepa, who is completely helpless.

\section{Endearing commands}

In Section I we saw that Marpa often uses khyod and the imperative stem in order to frame a direct command. In the examples in Section II Marpa addresses 
Milarepa in more sympathetic terms. In example (5) Marpa uses the prohibitive construction ( $m a$ byed) to remind Milarepa that all his hardships are for his own benefit. In example (6) he encourages Milarepa, telling him what he needs to do (byed dgos) to succeed in his meditation practice. In example (7) Marpa uses the imperative with a more familiar vocative term, addressing Milarepa as his son (bu). In example (8) Marpa uses the inclusive pronoun "us two" (rang re) with the imperative stem in order to implore that he and Milarepa perform a ritual together. In this example there is the least hierarchical distance between teacher and student. In the final example (9) from this section Marpa again uses khyod with the imperative, but in a much more affectionate tone. In all of the examples Marpa is still telling Milarepa what to do, but he is doing so in an encouraging or celebratory mood.

In the first example Marpa is alone with Milarepa, giving him teachings for the first time. It is an intimate moment. Instead of issuing a command with an imperative stem, Marpa uses the prohibitive to gently chide Milarepa. ${ }^{13}$

mthu chen kha sang gi ngas ma byas pa'i ham pa de 'dra ma byed //

$\begin{array}{llll}\text { mthu chen } & \text { kha sang gi } & \text { ngas } & \text { ma byas pa'i } \\ \text { Great Magician-VOC } & \text { yesterday-GEN } & \text { me-ERG NEG-done-GEN } \\ \text { ham pa } & \text { de 'dra } & \text { ma byed // } \\ \text { deception-[ABS] } & \text { this way } & \text { NEG-do-IMP }\end{array}$

"Great Magician! Don't falsely accuse me of a deception, like you did yesterday." (27a line 6)

In the same scene, Marpa commiserates with Milarepa that the path ahead will be very challenging.

(6) di 'dra byed dgos gsung na ro'i rnam thar dka' ba spyad tshul rnams mdor bsdus pa cig gnang nas / khyod kyis yong ba dka' mo yin //

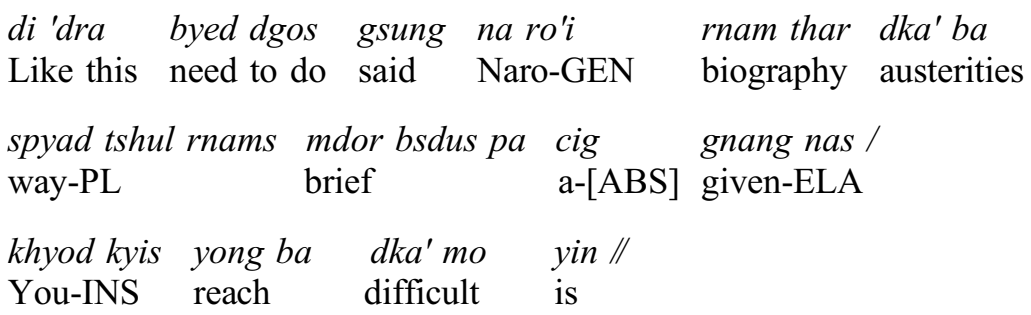

"You need to do this, he said, having narrated a brief account of the ways Naropa practised austerities. It will be difficult for you to measure up." (27b line 1)

13 Marpa also encourages Milarepa using the prohibitive: "Last night I was very hard on you, [but] don't be discouraged!" (dang ngas khyod la mang po rang 'thabs 'dug / ma dga' ba ma byed, 26a line 4). 
Marpa is still telling Milarepa what to do with the pronoun khyod, but it comes across as a soft imperative through the use of byed dgos (i.e. "You need to do", rather than "Do it!"). ${ }^{14}$

In the next example Marpa uses the imperative with the vocative bu kho de. ${ }^{15}$ This lends his speech a much more affectionate tone.

(7) bu kho de ${ }^{16}$ zla ba bcu gcig tsam stan gyi drod ma yal bar sgom nus pa dga' rab yin / da re cig bug ${ }^{17}$ sgo zhig la pha rgan nga'i 'gram du khams dub pa bseng ba / dang snyams skye tshul gyi gleng mo byed pa zhog cig //

bu kho de zla ba bcu gcig tsam stan gyi drod ma yal bar Son-VOC for eleven months cushion-GEN heat NEG-disappear-TRM

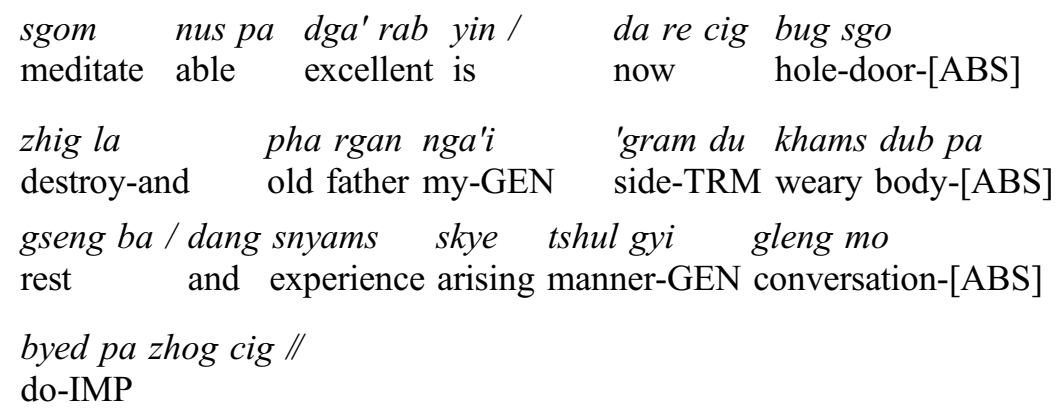

"Oh son! It is excellent that you were able to meditate for eleven months without your cushion losing its heat. ${ }^{18}$ Now break down the door to the cave! Rest your weary body at your old father's side and have a conversation about the types of experiences that arose [during your meditation retreat]!" (42a line 5)

14 Marpa uses dgos in a similar way later in the narrative: "Great Magician! If you wish for the dharma from your heart, you must relinquish even your life for it!" (snying nas chos 'dod pa yin na chos phyir srog kyang gtong dgos pas, 33b line 1).

15 The pronoun kho de may mean something like, "Hey you!" The Btsan lha dictionary gives the following definition: kho re zhes pa'i 'bod sgra ste / "It is an interjection or exclamation much like "hey you!' (59)". Although the exclamation kho re can indicate displeasure on the part of the speaker, it does not in the Milarepa Life Story. Marpa is quite happy with Milarepa at this point so kho de instead adds a tone of affection to the already familiar vocative $b u$. This reading is strengthened by a second instance of kho de in the Milarepa Life Story: Oh son! When you first arrived at my place ... (bu kho de / khyod dang por nga'i sar slebs pa'i tshe, 49b line 4). This occurs in the middle of one of Marpa's last speeches to Milarepa, where he indicates to his student that he will successfully promulgate the Buddhist teachings. Again, kho de adds an endearing sense to the vocative $b u$ (rather than just make a claim for attention).

16 de Jong provides bhu kho ste as one variant reading. Manuscripts A and C in de Jong's edition read bhu kho de.

17 Here all editions read bug where we might expect phug (cave). The "door (sgo)" in this case, is a temporary wall constructed to enclose a cave for the duration of a meditation retreat. Bug sgo could mean the "hole-door", in the sense of a "small window" left in the wall at the opening of the cave (used to send food in and excrement out).

18 Marpa simply means that Milarepa was particularly diligent, such that his cushion stayed warm throughout his meditation retreat. 
Immediately after this Marpa implores Milarepa that they perform a ritual offering together, using the first person inclusive pronoun rang re. ${ }^{19}$

rang re pha bu gnyis mngon rtogs sgom cho ga gyis //

$\begin{array}{llll}\begin{array}{l}\text { rang re pha bu } \\ \text { Us father and son }\end{array} & \begin{array}{l}\text { gnyis } \\ \text { two }\end{array} & \begin{array}{l}\text { mngon rtogs } \\ \text { clear realization }\end{array} & \begin{array}{l}\text { sgom } \\ \text { meditation }\end{array} \\ \text { cho ga } & \text { gyis // } & \\ \text { ritual-[ABS] } & \text { do-IMP } & \end{array}$

"Let the two of us, father and son, perform the ritual for the meditation on clear realization!" (42b line 1)

Marpa exuberantly declares that he and Milarepa should perform a ritual together. ${ }^{20}$ In this statement the inclusive pronoun "us (rang re)" is obviously to be read as "us two", as it is in apposition with the compound noun "father and son ( $p h a b u)$ ". ${ }^{21}$ Later, Marpa again uses rang re in the same formulation (i.e. with pha bu) as he is saying goodbye to Milarepa. ${ }^{22}$ The use of rang re with the imperative indicates the least hierarchical distance between Marpa and his student.

One final example shows that khyod is used with the imperative even with the utmost intimacy. Marpa implores that Milarepa sleep in the same room as him so they can have one more conversation before his student's final departure.

19 This first person inclusive pronoun is as an innovation of Middle Tibetan, for it is not found in Old Tibetan. Abel Zadoks, "Evidentials in Middle Tibetan texts: conference notes", unpublished manuscript read at the 37th International Conference on Sino-Tibetan Language and Linguistics, Lund, September 2004, p. 2.

20 Marpa uses gyis as the imperative form of bgyid ("to do"). Marpa never uses the more informal byos in the Life Story. In other commands, Marpa uses gyis as an auxiliary verb: "Great Magician! If you have wealth, then bring it here and receive the initiation!" (mthu chen khyod rang la nor yod na khyer shog dbang bskur gyis, 31b line 6) and "You should receive as many [of those teachings] as you can!" (khyod gyis ci longs gyis, 50a line 5-6).

21 In the early chapters of the Life Story people in Milarepa's home region use the pronoun rang re. Nathan W. Hill tentatively hypothesizes that it could be a dialect feature of Gung-thang ("Some Tibetan first-person plural inclusive pronouns", in Hanna Havnevik and Charles Ramble (eds), From Bhakti to Bon: Festschrift for Per Kvorne (Oslo: The Institute for Comparative Research in Human Culture / Novus Press, 2015), 248. The fact that Marpa (said to have been from Lho-brag) uses it twice in this story is a small piece of evidence against this conjecture. Marpa also uses the pronoun 'o cag. Hill provides four examples of this pronoun, tentatively concluding that it is inclusive ("Personalpronomina", 6). Marpa's single use of this pronoun coincides with this hypothesis, as he is speaking about his wife and himself together: "It is not the case that [Milarepa] did not forsake us. He did not forsake himself." ('o cag blos ma thongs pa min / kho rang blos ma thongs pa yin, 33a line 6).

22 "You coming here to present this request and finding me asleep is a sign that us two, father and son, will not meet again in this life." (khyod 'dir zhu ba 'bul du 'ongs pa dang / nga gnyid du song tug pa de / rang re pha bu tshe 'dir mi phrad pa'i rten 'brel yin, 49b line 6). 
nga la khyod rang do nub nga'i sar nyol / pha bu gleng mo byed pa yin //

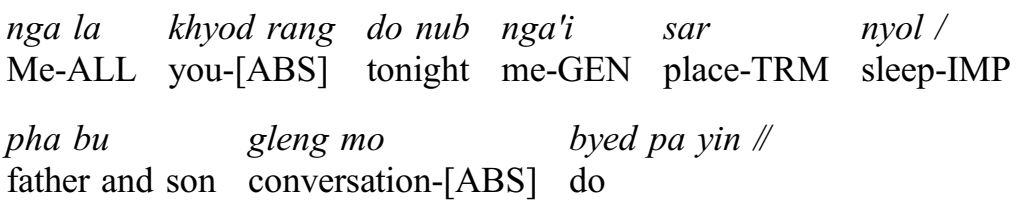

"You sleep near me tonight! Father and son will have a conversation." (52a line 1)

Here we have the familiar structure of a second person singular pronoun (khyod rang) combined with the imperative stem (nyol). Yet the context forces us to read this passage very differently from those with a similar grammatical structure given above in Section I. Marpa is not assuming the domineering stance used when forcing Milarepa to cast magical spells or build stone towers. On the contrary, Marpa is speaking as a father to a son and the passage as a whole is framed by the grief Marpa and Dakmema have for Milarepa's departure. In two other commands from this part in the story (folios 51a-52b) Marpa uses the same grammatical construction to implore Milarepa to keep his teachings in mind and not to forget him. ${ }^{23}$ In all these examples we must read the second person singular khyod in a much more affectionate manner, even though it is combined with the imperative stem.

In the examples in Section II Marpa tells Milarepa what to do by giving him advice and encouragement. There is much less distance between them. Sometimes this is evinced by a change in pronoun (e.g. rang re) or by the use of a familiar vocative (e.g. $b u$ ). In the last example, though, it is only through context that we know Marpa is being affectionate towards Milarepa.

23 "I indeed will not forget about you, and you also don't forget about me!" (ngas kyang khyod ma brjed par byed / khyod rang yang nga ma brjed par gyis, 51b line 5) and "You keep these final heart-teachings by me, your old father, in mind without forgetting" ( pha rgan ngas khyod rang la 'chad pa'i snying gtam gyi tha ma 'di rnams ma brjed par sems la chongs zhig, 53a line 1). In two of the manuscripts edited by de Jong (A and B) Marpa addresses Milarepa as khyed in these quotations. In the first quotation, the first "khyod" reads as khyed in manuscript B (de Jong, Mi la ras pa'i rnam thar, 103, line 19 , n. 25). In the second quotation, manuscript A reads khyed (ibid. 105, line 24, n. 10). The fact that khyed crops up here (i.e. when Milarepa is departing as Marpa's closest student) suggests that at least two authors felt that Milarepa holds a high social status at this particular point in the narrative. Milarepa's status is also contextually equated with Lama Ngokpa's in this section of the narrative. Marpa tells him to compare his understanding of the oral instructions with Lama Ngokpa. When they do it is said that Lama Ngoka is better at explaining the tantras (rgyud gyi bshad pa la khong lhag par 'dug), but that Milarepa's practice is comparable (nyams len la nga rang zhan rgyu $m i$ ' $d u g, 54 \mathrm{~b}$ line 3). As Lama Ngokpa is the only other person addressed by Marpa with khyed, perhaps the pluralis majestatis is used intentionally here to reflect Milarepa's increased social status. None of the manuscripts use khyed consistently in these three parting commands, so even as these variants are worth mentioning we cannot take them as a strong evidence for systematic pronoun usage (especially khyod vs. khyed) in the various editions of the Life Story. 


\section{Formal requests}

In Section I Marpa berates Milarepa, issuing commands that typically begin with khyod and end in the imperative stem. In Section II we saw that depending on the choice of pronoun and verb form, similar constructions can be used to give advice and encouragement. In a few cases, even khyod and the imperative are used in an affectionate sense. ${ }^{24}$ In Section III we see that even though Marpa uses khyod in positive and negative statements, its use always indicates his higher social status. For when Milarepa, Dakmema, and Lama Ngokpa entreat Marpa to do certain things they never address him with khyod or use the imperative. In the next two examples (10 and 11) Dakmema is asking Marpa to teach, but rather than using the imperative her speech is framed as a request (using honorific forms and the verb $z h u b a$ ).

(10) don med kyi mkhar las gyis mi sdug thag gcod pa 'dug / mthu chen la chos thugs rjes 'dzin par zhu /I

don med kyi mkhar las gyis mi sdug thag gcod pa 'dug/ Meaningless-GEN fortress-work-INS evil person certain exists mthu chen la chos thugs rjes 'dzin par zhu /l Great Magician-ALL dharma-[ABS] compassion-ERG hold-TRM request

"I am certain you are a bad man, through [forcing Milarepa to do] the meaningless work [of building] a fortress. I request that you remember Great Magician through compassion [and teach him] the dharma." (27a line 5)

(11) kho snying yang rje bar gda' bas / da bu 'di la chos cig gnang bar zhu /I

kho snying yang rje bar gda' bas / da bu 'di la

He-[ABS] compassion-TRM is-since now son him-ALL

chos cig gnang bar zhu/

dharma a-[ABS] give-TRM request

"Since he is one deserving compassion, now please give this son the dharma." (29b line 5)

Dakmema does not use the imperative towards Marpa, even though her requests are extremely urgent. Milarepa also addresses Marpa with the verb zhu ba, asking that he send beer to welcome Lama Ngokpa.

(12) de la bsu chang cig re ba 'dra lags pas gnang bar zhu //

de la bsu chang cig re ba

This-ALL welcoming-beer an expectation-[ABS]

24 Marpa also uses khyod in a compliment for Lama Ngokpa: "Someone like you can be called a disciple of the Secret Mantra, one whose oaths are kept" (gsang sngags gyi slob ma dam tshig can bya ba khyod'dra ba la zer ba yin, 38b line 2). Marpa is telling Lama Ngokpa that he is an excellent Buddhist practitioner. 
$\begin{array}{lllc}\text { 'dra } & \text { lag pas } & \text { gnang bar zhu / } \\ \text { seems } & \text { is-because } & \text { give-TRM } & \text { request }\end{array}$

"In this regard, since it seems there is an expectation for a welcomingbeer, I request that you send one." (37b lines 1-2)

Later, after Lama Ngokpa arrives, he requests specific Buddhist teachings from Marpa.

(13) khyad par snyan gyi shog ril gyis gdams ngag thugs rjes 'dzin par zhu /I khyad par snyan gyi shog ril gyis gdams ngag In particular-TRM aural-GEN scrolls-ERG oral instructions-[ABS]

$\begin{array}{lll}\text { thugs rjes } & \text { 'dzin par } & \text { zhu / } \\ \text { compassion-ERG } & \text { hold-TRM } & \text { request }\end{array}$

"Please hold me with compassion and [teach] the oral instructions, in particular with the aural scrolls." (38a line 5)

All of the requests made by Milarepa, Dakmema, and Lama Ngokpa have the exact same construction, ending with the verb "to humbly request (zhu ba)". Nobody uses the imperative when speaking to Marpa. Even though Milarepa's status changes dramatically in Milarepa Life Story, it would be unthinkable for him to address Marpa with the pronoun khyod. Instead of addressing Marpa by name, requests begin with honorific titles such as "Revered Lama (bla ma lags)", "Great Father Lama (yab bla ma chen po)", and "Precious Lama (bla ma rin po che)".

\section{Conclusion}

In the Milarepa Life Story Marpa issues many commands with the imperative stem. These commands indicate a varying level of distance between himself and the addressee depending on the pronoun or vocative (khyod, bu, rang re, etc.) used. In some contexts Marpa encourages Milarepa to persevere, using the prohibitive ma byed or the positive construction byed dgos. Marpa also uses a variety of monikers to address others, while his interlocutors never use pronouns such as khyod or the imperative. Instead they invariably use honorific titles and the verb "to humbly request (zhu ba)". The uniformity of such requests stands in stark contrast to the variety of terms and registers used to characterize Marpa's speech. Marpa's speech alone determines how close he is to an interlocutor at a given time, confirming both his status and the roles of his student, wife, and co-religionist.

$\begin{array}{llll}\text { Abbreviations } & & & \\ \text { Absolutive } & \text { [ABS] } & \text { Instrumental } & \text { INS } \\ \text { Allative } & \text { ALL } & \text { Negation } & \text { NEG } \\ \text { Elative Ergative } & \text { ELA } & \text { Plural } & \text { PL } \\ \text { Ergative } & \text { ERG } & \text { Question Marker } & \text { QSN } \\ \text { Genitive } & \text { GEN } & \text { Terminative } & \text { TRM } \\ \text { Imperative } & \text { IMP } & \text { Vocative } & \text { VOC }\end{array}$




\section{Appendix}

A complete list of Marpa's commands that use the imperative stem (or prohibitive) with a pronoun or vocative in reference to Milarepa, Dakmema, and Lama Ngokpa.

\section{Milarepa}

khyod kyi dpe gog de phyir thon (25a line 3 )

khyod. . .nas do phyir thon (25a line $6-25$ b line 1 )

khyod rang la kha ba 'di rnams la mthu thong (25b line 6)

da khyod rang yar 'brog pa rnams khyi lo skyin chug (26a line 2-3)

mthu chen kha sang gi ngas ma byas pa'i ham pa de 'dra ma byed (27b line 6)

mthu chen khyod rang da re zhig mkhar gyi rtsig 'phro zhog (29a line 2-3)

khyod rang la yod na khyer zhog (29a line 5-6)

da khyod rang khyams dang spe'u'i 'phro slong la mthar skyol (29b line 2)

mthu chen khyod rang la nor yod na khyer shog dbang bskur gyis (31b line 6)

bu kho de ... bug sgo shig ... gleng mo byed pa la shog cig (42a line 5)

rang re pha bu gnyis mngon rtogs sgom cho ga gyis (42b line 1)

khyod rang yang nga ma brjed par gyis (51b line 5)

khyod rang do nub nga'i sar nyol (52a line 1)

da khyod 'di nas bla ma rngog pa'i drung du song (52b line 2-3)

\section{Dakmema}

khyod rang bcos ba'i dpang po de gyis (28a line 1)

bdag med ma tsogs kyi sta gon gyis shig (42b line 1)

bdag med ma tsogs kyi 'khor lo bzang po zhig gi grabs gyis (46b line 5)

bdag med ma mchod pa bzang po zhig shoms shig (50a line 1)

bdag med ma tsogs dang mchod pa bzang po zhig zhom zhig (51a line 1)

\section{Lama Ngokpa}

khye ... khyer shog (36a line 6)

khye rang yang shog (36a line 6)

rngo ston chos rdor zer ba'i ma bcol ba byed mkhan khyod rang ... long shog (39a line 2) 